\title{
Research Paper Socio-economic analysis of small and marginal farmers in Jaipur district of Rajasthan
}

\author{
- Mohan Lal Jat, P.S. Shekhawat and Sonu Jain
}

See end of the paper for authors' affiliations

Correspondence to :

Sonu Jain

Department of Agricultural

Economics, Sri Karan

Narendra Agriculture

University, Jobner, Jaipur

(Rajasthan) India

Email: sonujain.ageco@

sknau.ac.in

Paper History :

Received : 11.06.2020,

Revised : 11.07.2020;

Accepted : 13.08 .2020
ABSTRACT : The study was conducted in Jaipur district of Rajasthan to know the socio-economic status of small and marginal farmers. A total of 60 farmers ( 30 farmers in each small and marginal category) were selected for the present investigation. The primary data relating to various socioeconomic variables were collected from the sample farmers by personal interview method using semistructured schedules and questionnaires for the purpose. Composite scales analysis like Udai Pareek revised scale-2019 and Modified BG Prasad scale-2019 were used to analyze the socio-economic status of small and marginal farmers, which have combinations of social and economic variables. The study revealed that, the socio-economic condition of small farmers was better than socio-economic condition of marginal farmers, according to composite scales analysis. On the basis of Udai Pareek revised scale, majority of marginal farmers (about $47.00 \%$ ) belonged to lower middle class whereas, majority of small farmers (about 53.00\%) belonged to middle class. Study further found that, in both categories of farmers, no farmer belonged to the lower and upper class. As per BG Prasad modified scale which is based on monthly income of household, majority of marginal farmers $(50.00 \%)$ belonged to upper middle class while, majority of small farmers $(60.00 \%)$ belonged to upper class. In both categories of sample farmers, no farmer belonged to lower and lower middle class.

KEY WORDS : Socio-economic, Udai Pareek revised scale, Modified BG Prasad scale, Farmers

How To Cite This Paper : Jat, Mohan Lal, Shekhawat, P.S. and Jain, Sonu (2020). Socio-economic analysis of small and marginal farmers in Jaipur district of Rajasthan. Internat. Res. J. Agric. Eco. \& Stat., 11 (2) : 170-175, DOI : 10.15740/HAS/IRJAES/11.2/170-175. Copyright@2020:Hind Agri-Horticultural Society. 